\title{
Consumo, Desempenho, Características de Carcaça e Biometria do Trato Gastrintestinal e dos Órgãos Internos de Novilhos Nelore Recebendo Dietas com Diferentes Níveis de Concentrado e Proteína ${ }^{1}$
}

\author{
Fabiano Ferreira da Silva², Sebastião de Campos Valadares Filho ${ }^{3}$, Luís Carlos Vinhas Ítavo 4 , \\ Cristina Mattos Veloso ${ }^{2}$, Mário Fonseca Paulino ${ }^{3}$, Rilene Ferreira Diniz Valadares ${ }^{5}$, \\ Paulo Roberto Cecon ${ }^{6}$, Poliana Albino Silva ${ }^{7}$, Renan Marques Galvão ${ }^{7}$
}

\begin{abstract}
RESUMO - Foram utilizados 36 novilhos Nelore inteiros, com peso vivo inicial de $240 \mathrm{~kg}$, distribuídos em oito tratamentos, com quatro diferentes níveis de concentrado nas dietas $(20 ; 40 ; 60$ e 80\%) e dois níveis de proteína bruta (PB) (15 e 18\%) e quatro animais referência.Foram determinados o desempenho, os rendimentos de carcaça, as porcentagens dos cortes básicos, o comprimento de carcaça, a área de olho de lombo, a espessura de gordura subcutânea, a porcentagem de músculo, gordura, osso, proteína, extrato etéreo eágua da carcaça, os pesos dos órgãos e vísceras. O consumo de MS não foi influenciadopelo nível de concentrado, na fase de recria, apresentando média de 7,06 kg/dia, porém, quando foi expresso em porcentagem do peso vivo (\% PV), estimaram-se consumos máximos de $2,59 \% \mathrm{PV}$ com $42,60 \%$ de concentrado. Na fase de engorda, os níveis de concentrado não influenciaram o consumo de MS, observando-se valores médios de 7,16 kg/dia e 1,80\% PV. O aumento do teor de proteína bruta da dieta, de 15 para 18\%, aumentou o consumo de MS, na fase de recria, mas não influenciou o consumo na fase de engorda. O GMD e a CA não foram influenciados pelos níveis de concentrado da dieta, independentemente da fase estudada. A dieta com $18 \%$ de $\mathrm{PB}$ propiciou, aos novilhos, 22 e $22,6 \%$ a mais de ganho de peso na recria e na engorda, respectivamente, comparada à dieta com $15 \%$ de PB. Na fase de recria, os níveis de concentrado da dieta não influenciaram os rendimentos de carcaça; na fase de engorda, o aumento da inclusão de concentrado na dieta aumentou linearmente o rendimento de carcaça em relação ao PV. Não foi verificado efeito dos níveis de concentrado e dos teores de PB da dieta sobre os cortes básicos estudados, nas fases de recria e de engorda. Os níveis de concentrado da dieta apresentaram tendências de aumento da porcentagem de músculo e de diminuição da porcentagem de gordura na carcaça. Na engorda, o maior teor de PB propiciou carcaça com maior porcentagem de músculo e menor porcentagem de gordura. Na fase de recria, os pesos dos rins, baço, pulmões, fígado e os constituintes do trato gastrintestinal não foram influenciados pelos níveis de concentrado e nem pelos teores de PB da dieta. Na engorda, os níveis de concentrado não influenciaram o peso dos órgãos e os teores de PB influenciaram positivamente os pesos dos rins, pulmões e fígado. Os pesos relativos do rúmen+retículo, estômagos e trato gastrintestinal apresentaram comportamento linear decrescente com o aumento dos níveis de concentrado. Os teores de PB não influenciaram os pesos dos constituintes do trato gastrintestinal em nenhuma das formas expressas, em ambas as fases estudadas.
\end{abstract}

Palavras-chave: carcaça, feno de tifton, Nelore, níveis de concentrado, níveis de proteína, órgãos, relação volumoso:concentrado, trato gastrintestinal

\section{Carcass Characteristics and Biometric of Gastrointestinal Tract and Internal Organs of Nellore Bulls Receiving Diets with Different Concentrate and Protein Levels}

\begin{abstract}
Thirty six Nellore bulls, with $240 \mathrm{~kg}$ initial live weight(LW), were used and distributed in eight treatments, with four different concentrate levels in the diets $(20 ; 40 ; 60$ and $80 \%)$ and two crude protein $(\mathrm{CP})$ levels (15 and 18\%) with four reference bulls. After the slaughter, the carcass dressing percentage, the basic cuts percentages, the carcass length, the loin eye area, the subcutaneous fat thickness, and the carcass muscle, fat, bone, protein, ether extract, water percentages, the organs and visceral weight were evaluated. DMI in the growing phase, expressed in $\mathrm{kg} /$ day, was not influenced by the concentrate level, presenting mean value of 7.06. But the DMI, expressed as a percentage of the LW (\% $\mathrm{LW}$ ), in this phase, demonstrated maximum consumptions of $2.59 \% \mathrm{LW}$, with $42.60 \%$ of concentrate. In the fattening phase, the concentrate levels did not influence the DMI, in any of the expressed ways, with mean values of $7.16 \mathrm{~kg} / \mathrm{day}$ and $1.80 \% \mathrm{LW}$. The increase in the diet CP level, from 15 to $18 \%$, caused a significant increase in the growing phase DMI, but it did not influence the consumption in the fattening phase. LWG and FC were not influenced by the concentrate levels of the diet, independent of the studied phase. The diet with $18 \%$ of CP propitiated, to the bulls, $22 \%$ and $22.6 \%$ more LWG in the growing and in the fattening phases, respectively, compared to the diet with $15 \%$ of CP. In the growing phase, the diet concentrate levels did not influence the carcass dressing percentage; in the fattening phase, the increase in concentrate caused a linear increase in the carcass dressing percentage in relation to the LW. No effect was verified for concentrate level and CP level on the studied basic cuts, in both growing and fattening phases. The diet concentrate levels tended to arise fat and to diminish muscle in the carcass. In the fattening phase, the greatest $\mathrm{CP}$ level presented a carcass with larger muscle percentage and smaller fat percentage. In the growing phase, the kidneys, spleen, lungs, liver and the gastrintestinal tract constituents weights were not influenced by the diet concentrate and CP levels. In the fattening phase, the concentrate levels did not influence the organs and the CP level had a positive influence on the kidneys, lungs and liver weights. The rumen+reticulum, stomaches and GIT relative weights presented a linear decreasing behavior with the increasing concentrate levels. The CP level did not influence the GIT constituents weights in any of the expressed forms, in both phases.
\end{abstract}

Key Words: carcass, concentrate levels, gastrointestinal tract, Nellore, protein levels, organs, roughage:concentrate ratio, Tifton hay

\footnotetext{
${ }^{1}$ Parte da tese de Doutorado em Zootecnia apresentada pelo primeiro autor à UFV. Financiada pela FAPEMIG; ${ }^{2}$ Professor do curso de Zootecnia - UESB - Itapetinga, BA. E.mail: ffsilva@uesb.br; ${ }^{3}$ Professor do Departamento de Zootecnia - UFV - Viçosa, MG. E.mail: svcfilho@ufv.br;

${ }^{4}$ Professor da Universidade Católica Dom Bosco - Campo Grande, MS; ${ }^{5}$ Professor do Departamento de Medicina Veterinária - UFV - Viçosa, MG. E.mail: svcfilho@ufv.br; ${ }^{6}$ Professor do Departamento de Informática - UFV - Viçosa, MG; ${ }^{7}$ Bolsista de Iniciação Científica/UFV - Viçosa, MG.
} 


\section{Introdução}

Nos sistemas de produção modernos de gado de corte, com o advento da informatização, tornou-se mais fácil a utilização de informações de desempenho do animal na determinação de seu potencial genético e sua habilidade em responder ao meio ambiente. Porém, estas informações não exprimem todo o potencial do animal e uma avaliação complementar das características da carcaça, que é, em última instância, $o$ alimento a ser produzido, torna-se preponderante.

$\mathrm{O}$ estudo de carcaça dos animais domésticos visa avaliar aquelas variáveis que podem ser, subjetiva ou objetivamente, medidas e relacionadas com aspectos qualitativos e quantitativos da mesma (Müller, 1987).

$\mathrm{O}$ rendimento de carcaça pode ser afetado por fatores como peso do conteúdo gastrintestinal, que é diretamente afetado pelo número de horas de jejum a que os animais foram submetidos, e pelo tipo de dieta (Meissner et al., 1995; Patterson et al., 1995), pelo peso e/ou idade de abate e pelo grau de engorda (Preston \& Willis, 1974), além dos pesos do couro, da cabeça e do trato gastrintestinal (Galvão et al., 1991; Jorge, 1993; Peron et al., 1993).

Os cortes básicos das carcaças de bovinos no mercado brasileiro são o dianteiro com cinco costelas, a ponta de agulha e o traseiro especial. Economicamente, seria desejável maior rendimento do traseiro especial, em relação aos outros cortes, pois nele se encontram as partes nobres da carcaça, que têm maior valor comercial. Segundo Luchiari Filho (2000), é desejável que uma carcaça tenha mais de $48 \%$ de traseiro especial, menos de $39 \%$ de dianteiro com cinco costelas e menos de $13 \%$ de ponta de agulha.

As proporções de gordura, músculo e osso dos animais são de grande interesse para a indústria e o consumidor (Hankins \& Howe, 1946). O componente de maior importância na carcaça é o músculo, já que este constitui a carne magra, comestível e disponível para venda.

A gordura é uma fração importante, pois influencia o aspecto visual da carcaça, a porção comestível e a qualidade da carne, além de servir como proteção (gordura subcutânea) contra a desidratação no resfriamento das carcaças (Moletta \& Restle, 1996). Contudo, o seu excesso pode diminuir o rendimento de carne magra.

Vários estudos foram realizados para se avaliarem os efeitos de diferentes níveis de concentrado na dieta sobre as características de carcaça, observando-se que, quando o peso de abate é predeterminado, as diferenças são pequenas para a maioria das caracte- rísticas (Araújo et al., 1998; Ferreira et al., 2000; Gesualdi Jr. et al., 2000).

$\mathrm{O}$ método mais preciso para se determinar a composição da carcaça é a realização de análises químicas em todos os tecidos do animal, após ter eliminado os conteúdos do trato digestivo e da bexiga. Provavelmente, o segundo melhor método seja a análise da carcaça. Entretanto, estas duas opções são muito dispendiosas e demoradas. Conseqüentemente, os trabalhos de pesquisa estão voltados para métodos simplificados, capazes de estimar a composição dos componentes mais importantes, com acurácia satisfatória. A procura de um método simples, que pudesse estimar com boa precisão a composição do corpo vazio e da carcaça, levou os pesquisadores a utilizarem diversos cortes da carcaça. Em experimento avaliando 194 carcaças, Hankins \& Howe (1946) propuseram corte da $9^{\mathrm{a}}, 10^{\mathrm{a}}$ e $11^{\mathrm{a}}$ costelas (seção HH) como estimador da composição física da carcaça e, a partir da análise química desta seção, chega-se à composição química da carcaça. Nour \& Thonney (1994) tentaram determinar a acurácia das equações de Hankins e Howe para novilhos da raça Holandesa e Angus, comparando a composição química da carcaça estimada pela seção HH e pela dissecação completa da meia carcaça direita. Concluíram que as equações de Hankins e Howe podem ser utilizadas, com razoável confiança, para estimar a composição da carcaça a partir da composição da seção HH, mas, para melhor acurácia e precisão, diferenças entre raças devem ser consideradas.

Em estudos de exigências energéticas dos animais, a determinação do tamanho relativo de seus órgãos internos é importante, já que diferenças nas partes não-integrantes da carcaça podem induzir variações nos requisitos energéticos para mantença (Owens et al.,1995). O tamanho dos órgãos internos também influencia o rendimento da carcaça (Jones et al., 1985).

Peron et al. (1993) compararam bovinos abatidos no início do experimento (mais leves) com animais submetidos à restrição alimentar ou alimentados à vontade (mais pesados) e concluíram que o peso do TGI foi menor em animais submetidos à restrição alimentar. Jorge et al. (1999) também observaram redução dos compartimentos do TGI e do fígado de bovinos submetidos à restrição alimentar. O tamanho do fígado de novilhos respondeu rapidamente às mudanças de consumo alimentar, apresentando desenvolvimento linear em

R. Bras. Zootec., v.31, n.4, p..**_***, 2002 
resposta ao consumo de energia metabolizável (Johnson et al., 1990).

O objetivo deste trabalho foi avaliar as características da carcaça e a biometria do trato gastrintestinal e dos órgãos internos de novilhos da raça Nelore nas fases de recria, até $360 \mathrm{~kg}$, e terminação, até $450 \mathrm{~kg}$, recebendo dietas com quatro níveis de concentrado e com dois níveis de PB.

\section{Material e Métodos}

O experimento foi realizado no Departamento de Zootecnia da Universidade Federal de Viçosa, em Viçosa-MG. Foram utilizados 36 novilhos Nelore inteiros, com peso vivo médio inicial de $241,7 \pm 41,2 \mathrm{~kg}$ em regime de confinamento. Quatro novilhos foram abatidos após o período de adaptação de 30 dias (grupo referência), servindo de referência nos estudos subseqüentes. Os 32 animais restantes foram pesados e distribuídos em oito tratamentos, com quatro diferentes níveis de concentrado nas dietas $(20,40,60$ e $80 \%)$ e dois níveis de PB (15 e 18\%), na base da MS, em esquema fatorial 4 × 2 (níveis de concentrado $\mathrm{x}$ níveis de proteína), no delineamento inteiramente casualizado, com duas repetições por tratamento. A fase de recria foi avaliada até $360 \mathrm{~kg}$ de peso vivo, e a fase de engorda, de 360 até $450 \mathrm{~kg}$ de peso vivo. O volumoso utilizado foi feno de gramínea
Cynodon dactylon(L) Pears. cultivar Tifton 85. As rações foram formuladas para atender as exigências de macro e microminerais para ganho de $1 \mathrm{~kg}$ de peso vivo/dia, segundo recomendações do NRC (1996) e para conter próximo de $32 \%$ de compostos nitrogenados não protéicos. A proporção dos ingredientes e a composição bromatológica das dietas e do feno encontram-se nas Tabelas 1 e 2 .

As determinações de matéria seca (MS), proteína bruta (PB), extrato etéreo (EE) e fibra em detergente neutro (FDN) foram feitas conforme técnicas descritas por Silva (1990). Os teores de nutrientes digestíveis totais (NDT) foram obtidos do experimento de Ítavo (2002).

As dietas foram fornecidas à vontade, uma vez ao dia, e ajustados de forma a manter sobras em torno de 5 a $10 \%$ do fornecido, com água permanentemente à disposição dos animais. Foi realizada uma pesagem dos animais no início do experimento e depois a cada 28 dias. À medida que o animal se aproximava do peso de abate preestabelecido, 360 ou $450 \mathrm{~kg}$ (recria e engorda, respectivamente), era pesado a intervalos de sete dias. Antes do abate, os animais foram submetidos a um jejum de 16 horas. Após o abate, o trato gastrintestinal foi pesado, esvaziado e lavado. Após escorrimento da água de lavagem, o trato gastrintestinal, bem como cabeça, couro, pés, rabo, sangue, rúmen, retículo, omaso,

Tabela 1 - Proporção dos ingredientes nos concentrados, na base da matéria natural

Table 1 - Ingredients proportion in the concentrate, as fed basis

\begin{tabular}{|c|c|c|c|c|c|c|c|c|}
\hline \multirow{2}{*}{$\begin{array}{l}\text { Nível de concentrado }(\%) \\
\text { Concentrate level } \\
\text { Teor de PB } \\
\text { CP content }\end{array}$} & \multicolumn{2}{|c|}{20} & \multicolumn{2}{|c|}{40} & \multicolumn{2}{|c|}{60} & \multicolumn{2}{|c|}{80} \\
\hline & 15 & 18 & 15 & 18 & 15 & 18 & 15 & 18 \\
\hline $\begin{array}{l}\text { Fubá de milho, } \% \\
\text { Corn meal }\end{array}$ & 88,72 & 59,74 & 91,96 & 77,10 & 93,05 & 83,20 & 95,37 & 86,16 \\
\hline $\begin{array}{l}\text { Farelo de soja, } \% \\
\text { Soybean meal }\end{array}$ & 4,75 & 32,44 & 4,38 & 18,35 & 4,03 & 13,50 & 1,76 & 11,01 \\
\hline $\begin{array}{l}\text { Uréia, } \% \\
\text { Urea }\end{array}$ & 2,93 & 4,65 & 1,58 & 2,43 & 1,16 & 1,70 & 1,25 & 1,35 \\
\hline $\begin{array}{l}\text { Calcáreo calcítico, \% } \\
\text { Limestone }\end{array}$ & 0,045 & 0,02 & 0,54 & 0,79 & 0,88 & 0,87 & 1,04 & 1,04 \\
\hline $\begin{array}{l}\text { Fosfato bicálcico, } \% \\
\text { Dicalcium phosphate }\end{array}$ & 2,78 & 2,42 & 1,12 & 0,94 & 0,57 & 0,45 & 0,33 & 0,20 \\
\hline $\begin{array}{l}\text { Sal comum, } \% \\
\text { Salt }\end{array}$ & 0,70 & 0,65 & 0,38 & 0,36 & 0,28 & 0,26 & 0,23 & 0,21 \\
\hline $\begin{array}{l}\text { Premix mineral, } \mathrm{g} / 100 \mathrm{~kg}^{1} \\
\text { Mineral premix }\end{array}$ & 84,04 & 84,04 & 42,02 & 42,02 & 28,00 & 28,00 & 21,00 & 21,00 \\
\hline
\end{tabular}

${ }^{1}$ Composição: Sulfato de zinco (Zinc sulfate), 80,00\%; Sulfato de cobre (Copper sulfate), 19,00\%; lodato de potássio (Potassium iodide), 0,50\%; Sulfato de cobalto (Cobalt sulfate), $0,25 \%$; Selenito de sódio (Sodium selenite).

R. Bras. Zootec., v.31, n.4, p.***_** 2002 
Tabela 2 - Teores médios de matéria seca (MS), proteína bruta (PB), extrato etéreo (EE), fibra em detergente neutro (FDN) e nutrientes digestíveis totais (NDT) das dietas experimentais e do feno de oito períodos

Table 2 - Average contents of dry matter (DM), crude protein (CP), ether extract (EE), neutral detergent fiber (NDF) and total digestible nutrients (TDN) of the experimental diets and of the hay

\begin{tabular}{|c|c|c|c|c|c|c|c|c|c|}
\hline \multicolumn{3}{|c|}{$\begin{array}{l}\text { Nível de concentrado (\%) } \\
\text { Concentrate level }\end{array}$} & \multicolumn{2}{|c|}{40} & \multicolumn{2}{|r|}{60} & \multicolumn{2}{|c|}{80} & \multirow[b]{2}{*}{$\begin{array}{c}\text { Feno } \\
\text { Hay }\end{array}$} \\
\hline $\begin{array}{l}\text { Teor de PB } \\
C P \text { content }\end{array}$ & 15 & 18 & 15 & 18 & 15 & 18 & 15 & 18 & \\
\hline $\begin{array}{l}\mathrm{MS}, \% \\
D M\end{array}$ & $88,2 \pm 1.6$ & $88,3 \pm 2,2$ & $88,1 \pm 2,6$ & $88,1 \pm 1,7$ & $87,8 \pm 2,1$ & $87,92 \pm 1,6$ & $87,6 \pm 2,5$ & $87,7 \pm 2,1$ & $88,6 \pm 2,3$ \\
\hline $\begin{array}{l}\mathrm{PB}^{1} \\
C P\end{array}$ & $15,7 \pm 0,47$ & $18,9 \pm 0,40$ & $15,1 \pm 0,48$ & $17,6 \pm 0,48$ & $15,1 \pm 0,41$ & $18,26 \pm 0,38$ & $14,5 \pm 0,30$ & $17,1 \pm 0,52$ & $14,1 \pm 0,56$ \\
\hline $\begin{array}{l}\mathrm{EE}^{1} \\
\mathrm{FDN}^{1,2}\end{array}$ & $\begin{array}{l}2,3 \pm 0,14 \\
62,4 \pm 3,1\end{array}$ & $\begin{array}{l}2,1 \pm 0,11 \\
60,6 \pm 2,6\end{array}$ & $\begin{array}{l}3,0 \pm 0,19 \\
48,6 \pm 2,0\end{array}$ & $\begin{array}{l}1,8 \pm 0,09 \\
46,5 \pm 2.7\end{array}$ & $\begin{array}{l}2,5 \pm 0,17 \\
37,9 \pm 1,5\end{array}$ & $\begin{array}{l}2,1 \pm 0,17 \\
34,6 \pm 2,9\end{array}$ & $\begin{array}{l}2,0 \pm 0,14 \\
25,9 \pm 1,8\end{array}$ & $\begin{array}{l}1,9 \pm 0,17 \\
19,7 \pm 1,6\end{array}$ & $\begin{array}{l}1,9 \pm 0,15 \\
74,5 \pm 3,9\end{array}$ \\
\hline $\begin{array}{l}N D F \\
\mathrm{NDT}^{1,3} \\
T D N\end{array}$ & $73,8 \pm 5,2$ & $73,2 \pm 4,7$ & $77,7 \pm 3,8$ & $79,3 \pm 5,0$ & $79,6 \pm 3,9$ & $81,5 \pm 4,5$ & $81,9 \pm 4,2$ & $78,4 \pm 5,5$ & $61,7 \pm 4,6$ \\
\hline
\end{tabular}

$1 \%$ na matéria seca (\% in dry matter).

${ }^{2}$ FDN corrigida para cinzas e proteína (NDF corrected for ash and protein).

3 Obtido em ensaio de digestibilidade com os mesmos animais (ITAVO, 2001) (Obtained by the digestibility experiment with the same animals).

abomaso, intestino delgado, intestino grosso, gordura interna (mesentério mais gorduras perirenal e pericardíaca), coração, rins, fígado, baço e pulmões, foram pesados para obtenção do peso do corpo vazio final.

Após lavagem e escorrimento da água, as carcaças foram divididas, com o auxílio de uma serra elétrica, em duas metades iguais, e pesadas. As duas meia-carcaças foram levadas à câmara fria, onde permaneceram por 18 horas, à temperatura de $-5^{\circ} \mathrm{C}$. Decorrido este tempo, as meia-carcaças foram pesadas. Da meia-carcaça direita, foi medido o comprimento e retirados os cortes básicos e determinados os seus pesos. Da meia-carcaça esquerda foram medidas a área de olho do músculo Longissimus dorsi (área de olho de lombo) e a espessura da gordura subcutânea, à altura da $12^{\mathrm{a}}$ costela. Ainda, a partir da meia-carcaça esquerda, obteve-se a seção transversal, incluindo a $9^{\mathrm{a}}, 10^{\mathrm{a}} \mathrm{e}$ $11^{\text {a }}$ costelas, segundo Hankins \& Howe (1946) seção $H H$, para determinação das proporções de músculo, gordura e ossos, segundo as equações propostas por estes autores:

$$
\begin{array}{ll}
\text { Músculo } & \hat{Y}=16,08+0,80 \mathrm{X} \\
\text { Tecido adiposo } & \hat{Y}=3,54+0,80 \mathrm{X} \\
\text { Ossos } & \hat{Y}=5,52+0,57 \mathrm{X}
\end{array}
$$

em que X é a porcentagem do componente na seção HH.

Em muitos trabalhos da literatura, inclusive nacional, a composição química da carcaça (água, proteína e EE) é determinada a partir da análise química dos constituintes da seção HH (músculo, ossos e gordura) e multiplicada pela composição física da carcaça, estimada pela seção $\mathrm{HH}$, conforme equações citadas acima. Com o objetivo de validar esta metodologia, foram escolhidas, da dieta com $15 \%$ de $\mathrm{PB}$, oito carcaças com composições físicas e químicas teoricamente distintas. Para tal, foram selecionadas, aleatoriamente, quatro carcaças de animais abatidos com $360 \mathrm{~kg}$ e quatro de animais abatidos com $450 \mathrm{~kg}$ de peso vivo, sendo uma de cada nível de concentrado, totalizando oito animais.

Nestas carcaças, realizou-se a dissecação completa da meia-carcaça direita, separando em ossos e músculo+gordura+aparas. O conjunto músculo+gordura+aparas foi moído integralmente e homogeneizado por 10 minutos em homogeneizador industrial para carne e, posteriormente, amostrado. Os ossos foram separados em costelas, vértebras e ossos longos, sendo pesados separadamente, para uma amostragem proporcional.

A partir da dissecação da meia-carcaça destes animais, determinaram-se as reais composições físicoquímicas da carcaça e do corpo vazio, sendo comparadas com a composição física e química estimada a partir da seção $\mathrm{HH}$ retirada da carcaça esquerda destes mesmos animais. O delineamento experimental utilizado para estes dados foi o inteiramente casualizado, com dois tratamentos (dissecação completa x seção HH) e oito repetições cada. A partir dos resultados de composição física e química das duas 
técnicas, foram feitas regressões para estimativa da composição química (água, proteína e EE) da carcaça e do corpo vazio, a partir da composição química da seção HH.

Os rendimentos de carcaça foram determinados em relação ao peso vivo e ao peso de corpo vazio. Os rendimentos dos cortes básicos foram determinados em relação ao peso da carcaça. Em relação aos cortes básicos, o dianteiro foi separado do traseiro entre a quinta e sexta costelas. O dianteiro compreendeu o acém e a paleta completa. $\mathrm{O}$ traseiro total foi dividido em ponta de agulha e traseiro especial, compreendendo o coxão e a alcatra completa.

Os resultados, em função dos níveis de concentrado, foram interpretados, estatisticamente, por regressão e comparação entre dissecação completa e seção HH, para determinação da composição química da carcaça, e todas as variáveis em função do teor de proteína da dieta foram interpretadas, estatisticamente, por meio de análises de variância, utilizando-se o Sistema de Análises Estatísticas e Genéticas - SAEG (UFV, 1995). Os critérios utilizados para escolha do modelo foram o coeficiente de determinação $\left(\mathrm{r}^{2} / \mathrm{R}^{2}\right.$, em \%) ajustado, que foi calculado como a relação entre a soma de quadrados da regressão e a soma de quadrados de tratamento, e a significância observada entre tratamentos por meio do teste $\mathrm{F}$, em níveis de 1 ou $5 \%$ de probabilidade. Os coeficientes de regressão foram comparados pelo teste "t" a 1 e 5\% de probabilidade.

\section{Resultados e Discussão}

Encontram-se na Tabela 3 as médias e regressões ajustadas dos consumos diários de MS, ganho médio diário, conversão alimentar e dias em confinamento, nas fases de recria e engorda.

$\mathrm{O}$ consumo de MS, expresso em $\mathrm{kg} / \mathrm{dia}$, não foi influenciado $(\mathrm{P}>0,05)$ pelo nível de concentrado, na

Tabela 3 - Médias, coeficientes de variação ( $C V$, \%) e equações de regressão ajustadas dos consumos diários de matéria seca (CMS), ganhos médios diários de peso vivo (GMD), conversão alimentar (CA) e dias em confinamento (DC) em função do nível de concentrado (nc) e teor de PB na dieta, nas fases de recria e de engorda e os respectivos coeficientes de determinação $\left(r^{2} / R^{2}\right)$

Table 3 - Means, coefficient of variation (CV, \%) and fitted regression equations for dry matter intake (DMI), live weight gain (LWG), feed efficiency (FE) and days in trial (DT) for concentrate level (CL) and CP content in the diet, in the growing and fattening phases, and the respective coefficients of determination $\left(r^{2}\right)$

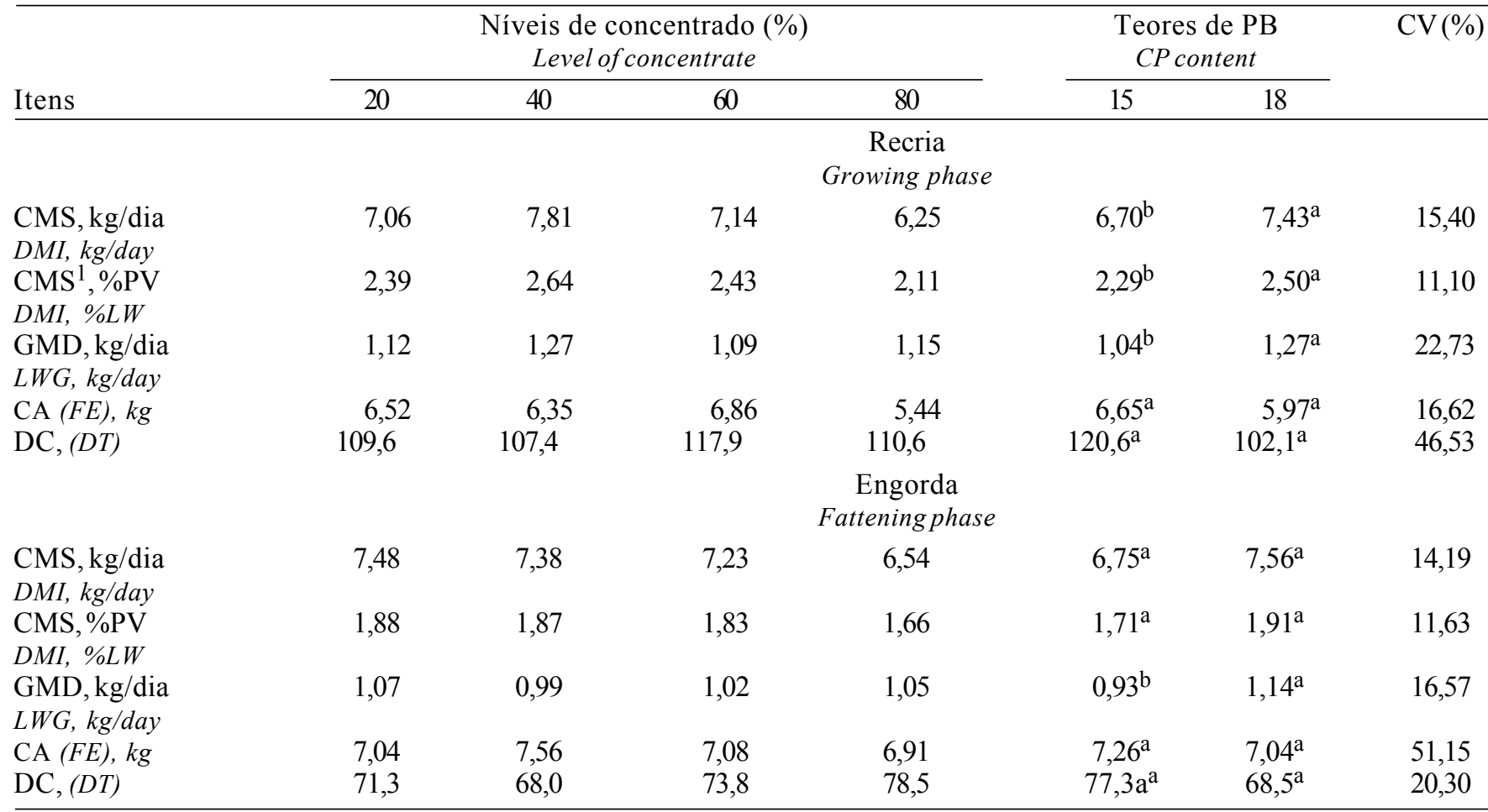

Médias seguidas de pelo menos uma mesma letra na linha, para os teores de PB, não diferem a $1 \%$ de probabilidade pelo teste $\mathrm{F}$ (Means followed by the same letter, within a row, for the CP contents, do not differ at $1 \%$ of probability by $F$ test).

${ }^{1} \hat{Y}=1,93966+0,0306771^{* *} n c-0,000360165^{\star *} n c^{2} R^{2}=0,96$;

** Significativo a $1 \%$ de probabilidade, pelo teste "t" (Significant at $1 \%$ of probability, by $t$ test).

R. Bras. Zootec., v.31, n.4, p. ${ }^{* * \star * * * *}, 2002$ 
fase de recria, apresentando média de 7,06. Quando o consumo de MS foi expresso em porcentagem do peso vivo (\% PV), nesta fase, demonstrou comportamento quadrático em relação ao nível de concentrado, com consumos máximos estimados de $2,59 \% \mathrm{PV}$ com $42,60 \%$ de concentrado. Na fase de engorda, os níveis de concentrado não influenciaram o consumo de MS, observando-se valores médios de 7,16 kg/dia e $1,80 \%$ PV.

Avaliações de desempenho de bovinos na recria, em confinamento, são escassas, talvez por não ser uma prática comum e economicamente viável. Avaliações do consumo de MS em resposta a diferentes níveis de concentrado, durante o período de engorda, expresso em \% PV, revelaram respostas positivas lineares (Ferreira et al., 1999); respostas quadráticas, de acordo com Gesualdi et al. (2000), e ausência de qualquer resposta, como observado neste experimento e por Véras et al. (2000). Os resultados de consumo de MS em relação aos níveis de concentrado são variáveis, dependendo da raça e da dieta fornecida, entre outros fatores.

$\mathrm{O}$ consumo de $\mathrm{MS}$, expresso em $\mathrm{kg} / \mathrm{dia}$, não foi influenciado $(\mathrm{P}>0,05)$ pelo nível de concentrado, nas fases de recria e de engorda, apresentando média de 7,06 e de $7,16 \mathrm{~kg} / \mathrm{dia}$, respectivamente. O consumo de MS, quando foi expresso em porcentagem do peso vivo (\% PV), na fase de recria, demonstrou comportamento quadrático em relação ao nível de concentrado, com consumos máximos estimados de 2,59\% PV com 42,60\% de concentrado. Na fase de engorda, os níveis de concentrado não influenciaram o consumo de MS, observando-se valores médios de 7,16 kg/dia; $1,80 \%$ PV.

$\mathrm{Na}$ engorda, mesmo com $20 \%$ de concentrado, o consumo não foi limitado fisicamente, sendo respaldado pelo bom valor de NDT desta dieta $(>73 \%$, Tabela 2). Segundo Conrad et al. (1964), em dietas com digestibilidade maior que $66 \%$, o consumo de MS é controlado por fatores fisiológicos, o que provavelmente ocorreu neste estudo.

$\mathrm{O}$ aumento do teor de proteína bruta da dieta, de 15 para $18 \%$, elevou o consumo de $\mathrm{MS}(\mathrm{P}<0,01)$, na fase de recria. Todavia, na fase de engorda, o consumo não foi influenciado pelo teor de proteína, embora a dieta com $18 \%$ de PB tenha apresentado tendência de maior consumo. $\mathrm{O}$ teor de $\mathrm{PB}$ da dieta influenciou positivamente $(\mathrm{P}<0,01)$ o ganho médio diário nas duas fases. A dieta com $18 \%$ de PB propiciou, aos novilhos, 22,1 e $22,6 \%$ a mais de ganho de peso na recria e na engorda, respectivamente, comparada à dieta com 15\% de PB (Tabela 6). Isto permitiu que os animais das dietas com maior teor de proteína tivessem tendência de menor período em confinamento.

O ganho médio diário (GMD), a conversão alimentar (CA) e os dias em confinamento (DC) não foram influenciados $(\mathrm{P}>0,01)$ pelos níveis de concentrado na dieta. Na recria, as médias de GMD, CA e DC foram 1,15 kg/dia, 6,29 e 111,38 dias, respectivamente e na fase de engorda, de 1,05 kg/dia, 7, 15 e 71,8 dias, respectivamente. Estes resultados não eram esperados, uma vez que o valor energético dos concentrados é superior ao da maioria dos volumosos comumente utilizados em confinamento. A possível explicação para estes fatos seria, talvez, o bom valor nutritivo do feno utilizado neste experimento, que propiciou às dietas, mesmo aquelas com apenas $20 \%$ de concentrado, uma digestibilidade da MS acima de $75 \%$ (Ítavo, 2002). Contribuindo com estes resultados, o potencial genético dos animais utilizados neste experimento, talvez, não tenha permitido que os ganhos fossem maiores com o aumento do valor energético da dieta, sendo já atingidos na dieta de menor valor energético ( $20 \%$ de concentrado).

As análises de variância não evidenciaram a existência de interação de níveis de concentrado com teor de proteína bruta $(\mathrm{P}>0,01)$, para qualquer variável de característica de carcaça e fase estudada. Estão apresentados, na Tabela 4, os rendimentos de carcaça, em relação ao peso vivo (RCPV) e em relação ao peso de corpo vazio (RCPCVZ), assim como o conteúdo do trato gastrintestinal, por nível de concentrado e por porcentagem de PB na dieta, nas fases de recria e engorda.

$\mathrm{Na}$ fase de recria, os níveis de concentrado da dieta não influenciaram $(\mathrm{P}>0,01)$ os rendimentos de carcaça expressos em relação ao peso vivo ou em relação ao peso de corpo vazio, mesmo tendo o peso do conteúdo do trato gastrintestinal diminuído linearmente $(\mathrm{P}<0,01)$ com o aumento dos níveis de concentrado. Os rendimentos de carcaça, expressos em relação ao peso vivo e em relação ao peso de corpo vazio, apresentaram respectivos valores médios de 57,4 e 64,3\%.

$\mathrm{Na}$ fase de engorda, o aumento da inclusão de concentrado na dieta elevou linearmente $(\mathrm{P}<0,01) \mathrm{o}$ rendimento de carcaça em relação ao peso vivo. $\mathrm{O}$ principal fator que influenciou este aumento de rendimento foi a diminuição linear do peso do conteúdo do trato gastrintestinal com o aumento dos níveis de concentrado na dieta, pois as dietas com maiores 
Tabela 4 - Médias, coeficientes de variação (CV, \%) e equações de regressão ajustadas para os rendimentos de carcaça em relação ao peso vivo (RCPV) e peso corporal vazio (RCPCVZ), expressos em \%, e para o peso do conteúdo do trato gastrintestinal (CTGI), expresso em kg, por nível de concentrado (NC) e teor de PB na dieta, nas fases de recria e engorda e os respectivos coeficientes de determinação $\left(\mathrm{r}^{2}\right)$

Table 4 - Means, coefficient of variation (CV, \%) and fitted regression equations for carcass yield in relation to live weight (CYLW) and empty body weight (EBW), in \%, and for the weight of gastrointestinal tract content (GTC), in kg, for concentrate level (NC) and CP content in the diet, in the growing and fattening phases, and the respective coefficients of determination $\left(r^{2}\right)$

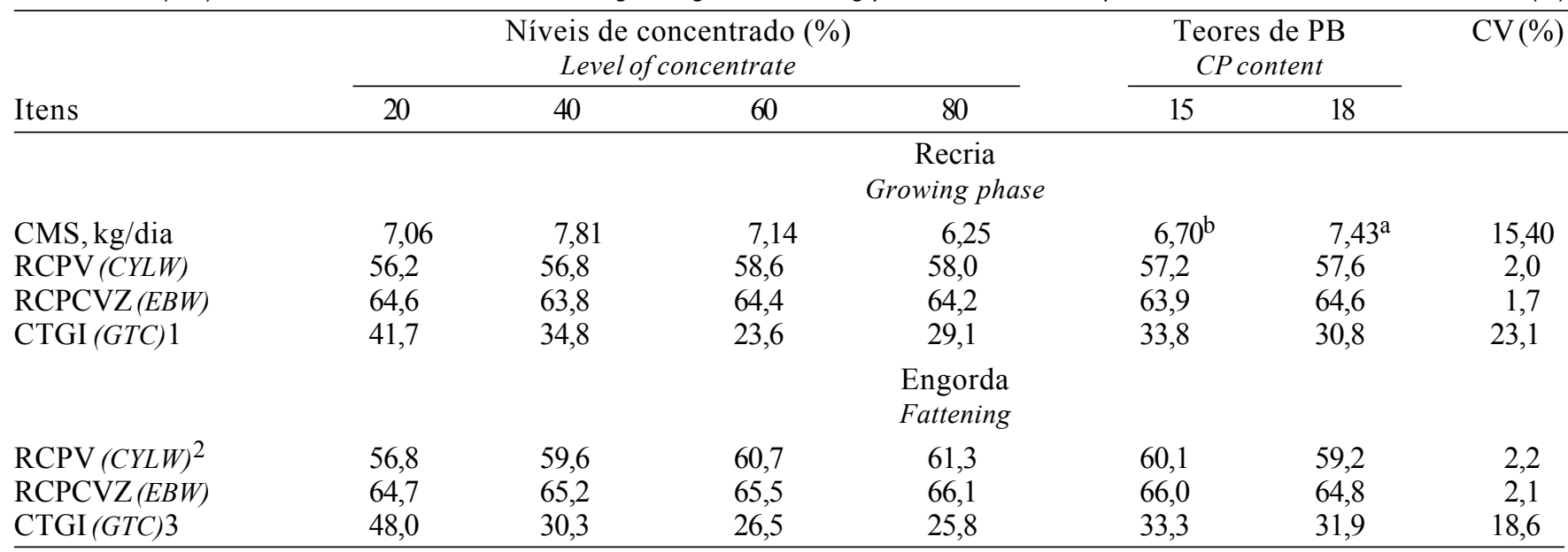

${ }^{1} \hat{Y}=44,5308-0,24473^{* *} \mathrm{nc} r 2=0,66 ; 2=55,9882+0,0734178^{* *} \mathrm{nc} \mathrm{r} 2=0,89 ; 3=50,2427-0,347619^{* *} \mathrm{nc} \mathrm{r} 2=0,76$.

** Significativo a $1 \%$ de probabilidade, pelo teste "t" (Significant at $1 \%$ of probability, by $t$ test).

níveis de concentrado apresentaram maior digestibilidade, 75,$7 ; 79,9 ; 79,9$; e $80,8 \%$ para os níveis de $20,40,60$ e $80 \%$ de concentrado na dieta, respectivmente. Segundo Geay (1975), citado por Jorge et al. (1997), os resultados de rendimento obtidos são mais consistentes quando este é calculado em relação ao peso corporal vazio, visto que o peso do conteúdo gastrintestinal varia amplamente (de 10 a $20 \%$ do peso vivo) em função do sistema de alimentação. Oliveira (1998) e Gesualdi Jr. et al. (2000), avaliando os efeitos dos níveis de concentrado sobre o rendimento de carcaça, em relação ao peso vivo, observaram aumentos lineares, mas, quando o rendimento foi expresso em relação ao peso de corpo vazio, não houve mais efeito dos níveis de concentrado. $\mathrm{O}$ valor médio do rendimento de carcaça, em relação ao peso de corpo vazio, foi de 65,4 , próximo aos citados na literatura para animais Nelore e F1 europeu x zebu (Oliveira, 1998; Jorge et al., 1999; Ferreira et al., 1999; Gesualdi Jr., et al., 2000).

Os teores de $\mathrm{PB}$ da dieta não influenciaram $(\mathrm{P}>0,01)$ o rendimento de carcaça e o peso do conteúdo do trato gastrintestinal, nas duas fases estudadas.

Os rendimentos dos cortes básicos da carcaça paleta, acém, ponta de agulha, alcatra completa e coxão - estão apresentados na Tabela 5. Não foram verificados efeitos dos níveis de concentrado e dos teores de $\mathrm{PB}$ da dieta $(\mathrm{P}>0,01)$ sobre os cortes estudados, nas fases de recria e engorda, com exceção do rendimento de traseira especial (RTE), que sofreu efeito dos teores de PB na fase de recria. Segundo Berg \& Butterfield (1979), independentemente da raça, o animal tende a manter, dentro de certos limites, um equilíbrio entre os quartos traseiro e dianteiro e, conseqüentemente, sobre os cortes.

Oliveira (1998), avaliando o efeito dos níveis de concentrado sobre os cortes básicos da carcaça de Nelores, na fase de engorda, observou respostas quadrática e linear, respectivamente, para rendimento de acém e ponta de agulha e de alcatra. Entretanto, Ferreira et al. (2000) e Gesualdi Jr. et al. (2000), variando os níveis de concentrado na dieta de animais F1 europeu x zebu, não encontraram efeitos significativos sobre os cortes básicos da carcaça. As médias das porcentagens de traseiro e de dianteiro foram 60,7 e $39,3 \%$, respectivamente, na fase de recria, e 58,8 e $41,2 \%$, respectivamente, na fase de engorda.

As médias e as equações de regressão ajustadas do comprimento da carcaça, da área de olho de lombo e da espessura de gordura subcutânea estão apresentadas na Tabela 6. O teor de $\mathrm{PB}$ da dieta não influenciou estas variáveis, independentemente da forma expressa (valores absolutos ou \% do PCVZ) e da fase de avaliação (recria ou engorda). 
Tabela 5 - Médias e coeficientes de variação (CV, \%) para os rendimentos de paleta (RPAL), acém completa (RACEM), dianteiro, alcatra completa (RALC), coxão (RCOX), traseiro especial (RTE), ponta de agulha (RPA), em \%, e traseiro, em função do nível concentrado e do teor de PB na dieta, nas fases de recria e engorda

Table 5 - Means, coefficient of variation (CV, \%) for yields (\%) of shoulder (SY), whole acem (WAY), forehind (FY), whole "alcatra" cut $(W A C Y)$, round $(R Y)$, pistola style cut $(P S C Y)$, spare ribs $(S R Y)$, in \%, and forequarter $(F Y)$ on the concentrate level and $C P$ content in the diet, in the growing and fattening phases

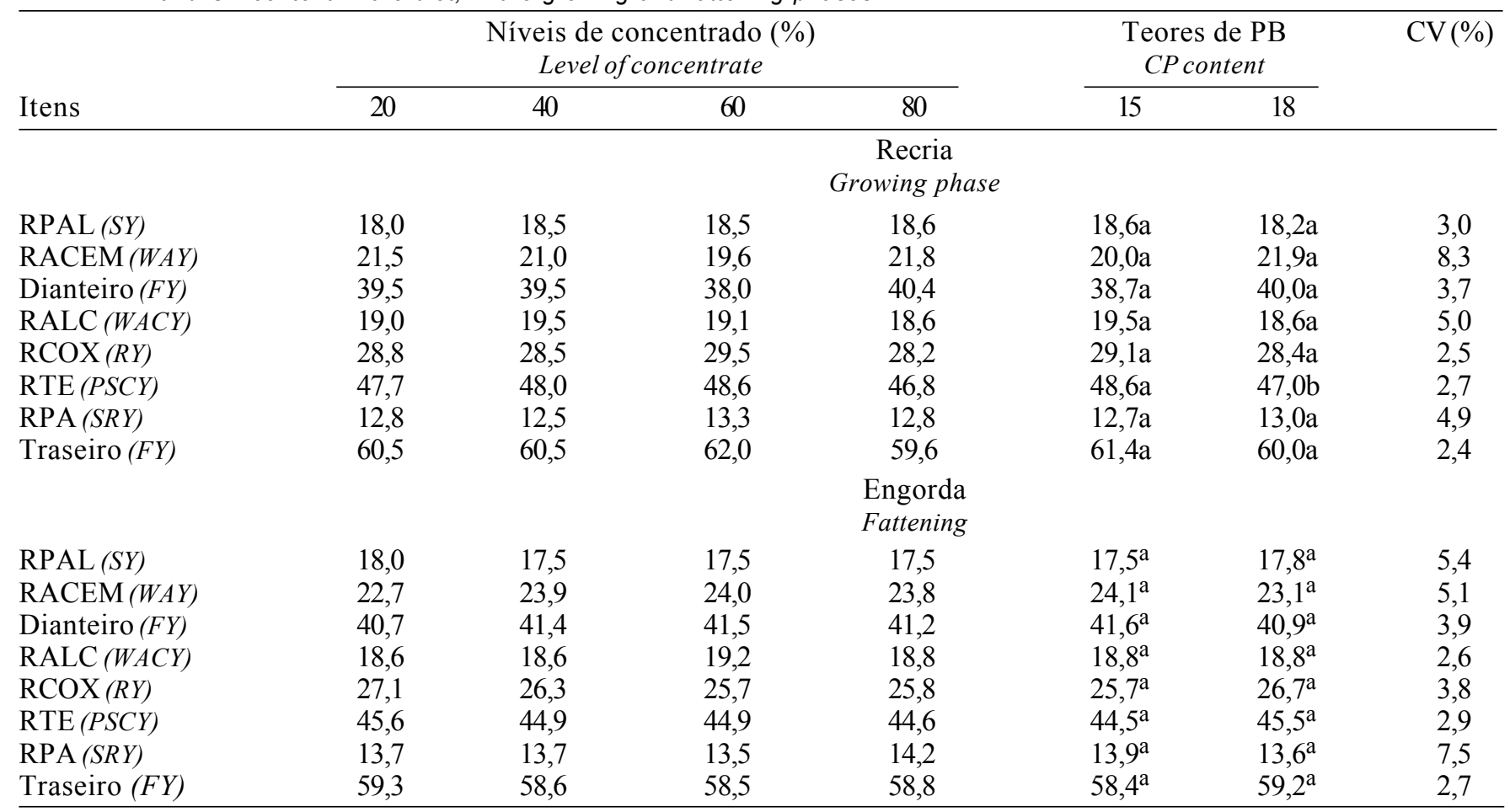

Médias seguidas de pelo menos uma mesma letra na linha, para os teores de PB, não diferem a $1 \%$ de probabilidade pelo teste $\mathrm{F}$ Means followed by the same letter, within a row, for he CP contents, do not differ at $1 \%$ of probability by $F$ test.

Na fase de recria, os níveis de concentrado da dieta não influenciaram $(\mathrm{P}>0,05)$ o comprimento da carcaça, a área de olho de lombo e a espessura de gordura subcutânea, quando expressos em valores absolutos. Quando o comprimento da carcaça e a área de olho de lombo foram expressos em \% do PCVZ, estas variáveis apresentaram comportamento linear decrescente $(\mathrm{P}<0,01)$ com o aumento do concentrado na dieta. Possivelmente, a diminuição do comprimento da carcaça com o aumento do nível de concentrado, com o abate realizado a um peso constante, indica maior compacidade destes animais, conforme foi observado por Muniz et al. (1997) e Ferreira et al. (2000). A diminuição da área de olho de lombo, com o aumento do nível de concentrado, pode indicar menor porcentagem de músculo na carcaça, em função de maior acúmulo de gordura.

O comprimento de carcaça, a área de olho de lombo e a espessura de gordura subcutânea não foram influenciados pelos níveis de concentrado da dieta, na fase de engorda, e apresentaram valores médios de $110,38 \mathrm{~cm}, 82,49 \mathrm{~cm}^{2}$ e 4,09 mm, respec- tivamente. A possível explicação para estes fatos seria o bom valor nutritivo do feno, utilizado neste experimento, que propiciou bom valor nutritivo a todas as dietas, inclusive aquela com menor níveis de concentrado, conforme pode ser observado nos valores de NDT das dietas (Tabela 2), e também o fato de o abate ter ocorrido em peso constante. Resultados semelhantes também foram encontrados por Oliveira (1998) e Gesualdi Jr. et al. (2000), trabalhando com animais Nelore e F1 Limousin x Nelore, respectivamente, recebendo diferentes níveis de concentrado.

Os animais zebuínos, principalmente os inteiros, eram tidos como possuidores de carcaças de qualidade inferior, principalmente em função da deficiência de gordura de cobertura. Com a falta da cobertura de gordura, a carcaça dos bovinos, durante o resfriamento, desenvolve um escurecimento da parte externa dos músculos, que prejudica o aspecto, e um encurtamento celular, que prejudica o paladar e, conseqüentemente, deprecia o valor comercial. Isto justifica, em parte, o desconto que os frigoríficos costumam impor sobre o valor pago no abate de animais inteiros. Pelos 
resultados deste trabalho, pode-se afirmar que animais Nelore apresentam uma cobertura de gordura subcutânea satisfatória para uma boa preservação (>3 mm, Luchiari Filho, 2000), se manejados em condições nutricionais favoráveis. Somam-se a este resultado, os encontrados por Moura et al. (1998) e Oliveira (1998), que obtiveram médias de espessura de gordura subcutânea de 3,4 e 4,3 mm, respectivamente, avaliando Nelores inteiros.

$\mathrm{Na}$ Tabela 7, estão apresentadas as composições física e química da carcaça, estimada pela seção HH e pela determinação da dissecação da meia-carcaça. As porcentagens de músculo+gordura $(86,8 \%)$ e de ossos $(14,6 \%)$ da carcaça estimada pela seção HH não diferiram das da composição física real da carcaça $(85,2$ e $14,8 \%$, respectivamente). Todavia, a composição química (proteína, lipídios, e água) estimada pela seção HH superestimou o conteúdo de extrato etéreo e subestimou o de água, sendo adequada para estimar o teor de prote- ína da carcaça. Ainslie et al. (1993) e Nour \& Thonney (1994) compararam a estimativa da composição química da carcaça, pela seção $\mathrm{HH}$, de novilhos da raça Holandesa e Holandês x Angus, respectivamente, com a moagem completa da meiacarcaça esquerda e posteriores análises químicas. As equações superestimaram a quantidade de lipídios na carcaça e subestimaram a quantidade de água, resultado semelhante ao deste experimento. Possivelmente, segundo Ainslie et al. (1993), isto se deve ao fato de as equações serem desenvolvidas com animais mais velhos e raças de corte com maior porcentagem de gordura corporal.

Foram ajustadas equações para estimar a porcentagem de lipídios e de água na carcaça, de lipídios, água e proteína no corpo vazio, a partir da porcentagem de lipídios na seção HH:

$$
\begin{array}{ll}
\text { \% lipídios na carcaça } & \hat{Y}=1,5113+0,6832 * \mathrm{X}, \mathrm{r}^{2}=0,75 \\
\text { \% água na carcaça } & \hat{Y}=71,8989-0,6006^{*} \mathrm{X}, \mathrm{r}^{2}=0,86 \\
\text { \% proteína na carcaça } & \hat{Y}=17,9730+0,0440 * \mathrm{X}, \mathrm{r}^{2}=0,77
\end{array}
$$

Tabela 6 - Médias, coeficientes de variação (CV, \%) e equações de regressão ajustadas para o comprimento da carcaça (CCAR), a área de olho de lombo ( $A O L)$ e a espessura de gordura subcutânea (EGS), para as medidas absolutas e para a medida relativa ao peso vazio, em função do nível de concentrado (nc) e teor de PB na dieta, nas fases de recria e engorda e os respectivos coeficientes de determinação $\left(\mathrm{r}^{2}\right)$

Table 6 - Means, coefficient of variation (CV, \%) and fitted regression equations for the carcass length(CL), loin eye area (LEA), subcutaneous fat thickness (SFT) and relative measure to live weight, as a function of concentrate level(NC) and CP content in the diet, in the growing and fattening phases, and the respective coefficients of determination $\left(r^{2}\right)$

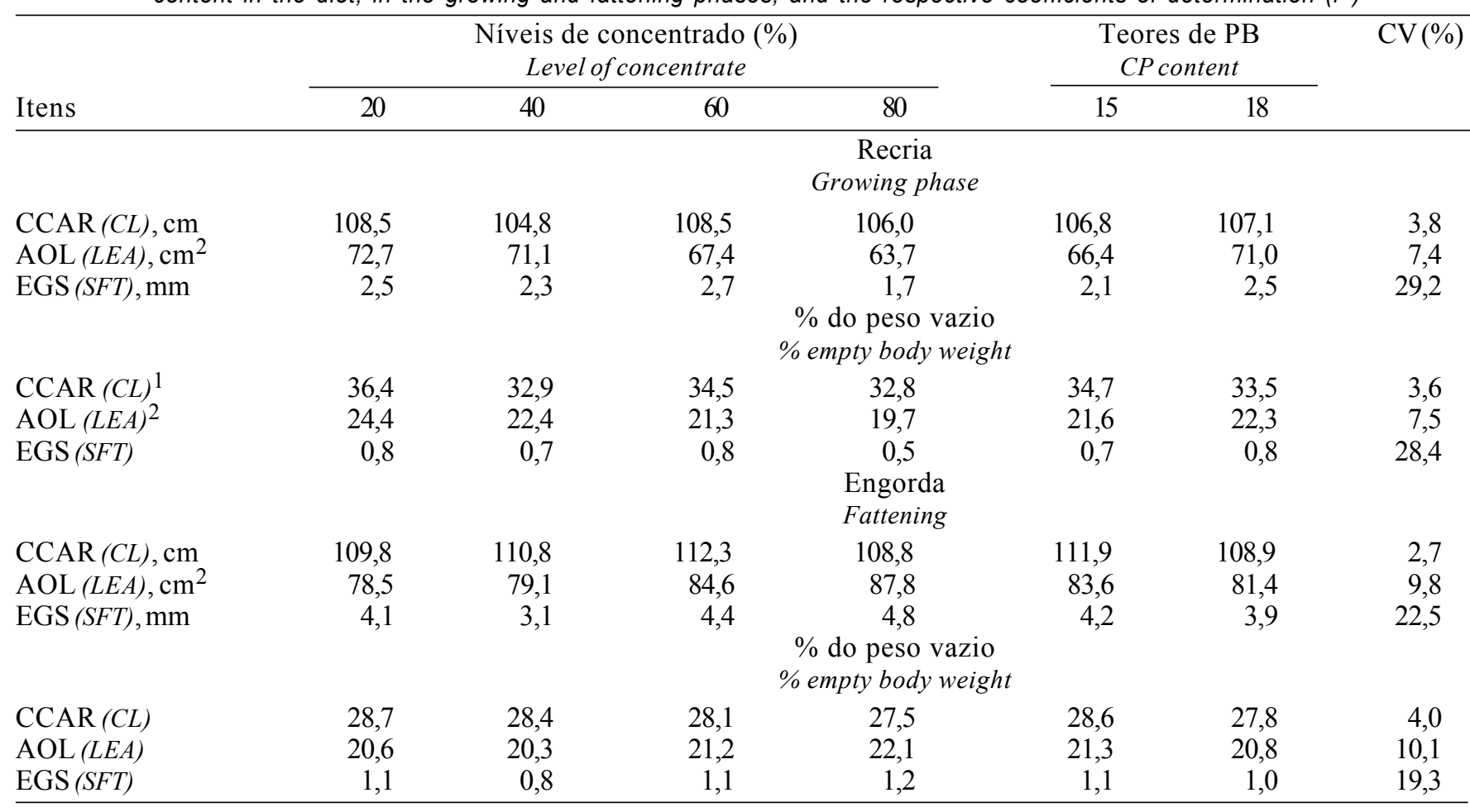

$1 \hat{Y}=36,4411-0,0463137^{* *} \mathrm{nc} \mathrm{r} 2=0,51$;

$2 \hat{Y}=25,7500-0,076288^{* *}$ nc $r 2=0,99$

** Significativo a $1 \%$ de probabilidade, pelo teste "t" (Significant at $1 \%$ of probability, by $t$ test).

R. Bras. Zootec., v.31, n.4, p.***_**, 2002 
$\%$ lipídios no corpo vazio $\hat{Y}=5,3424+0,6020 * \mathrm{X}, \mathrm{r}^{2}=0,56$

$\%$ água no corpo vazio $\quad \hat{Y}=66,7493-0,4251^{*} \mathrm{X}, \mathrm{r}^{2}=0,51$

\% proteína no $\quad \hat{Y}=17,9987-0,1006 * \mathrm{X}+0,1584 * \mathrm{Z}$, corpo vazio $\quad \mathrm{r}^{2}=0,59$

em que $\mathrm{X}=\%$ de lipídio na seção $\mathrm{HH}$ e $\mathrm{Z}=\%$ de proteína na seção $H H$.

Os teores de proteína na carcaça não apresentaram boas estimativas a partir da composição química da seção HH. A porcentagem de proteína da carcaça foi calculada por meio da multiplicação da composição física da carcaça (estimada pela seção $\mathrm{HH}$ ) pela composição química dos respectivos cons- tituintes da seção HH (músculo, ossos e gordura).

As duas primeiras equações foram utilizadas para estimar a composição química da carcaça dos animais experimentais, apresentada na Tabela 8. Os coeficientes de determinação das equações para estimativa da composição química da carcaça, a partir da composição química da seção $\mathrm{HH}$, apresentaram-se maiores que os das equações para estimativa da composição química do corpo vazio. Alleoni et al. (1997), trabalhando com número maior de animais Nelore, obtiveram equações que estimaram com alta precisão as porcentagens de água e de extrato etéreo corporal, a partir da

Tabela 7 - Composição física e química da carcaça pelos métodos de dissecação da meia-carcaça e da seção HH Table 7 - Physical and chemical carcass composition by the half carcass dissection and HH section methods

\begin{tabular}{|c|c|c|c|c|c|}
\hline & \multicolumn{2}{|c|}{$\begin{array}{l}\text { Composição física, \% } \\
\text { Physical composition }\end{array}$} & \multicolumn{3}{|c|}{$\begin{array}{l}\text { Composição química, \% } \\
\text { Chemical composition }\end{array}$} \\
\hline & $\begin{array}{l}\text { Músculo+gordura } \\
\text { Muscle }+ \text { fat }\end{array}$ & $\begin{array}{l}\text { Osso } \\
\text { Bone }\end{array}$ & $\begin{array}{l}\text { Água } \\
\text { Water }\end{array}$ & $\begin{array}{l}\text { Proteína } \\
\text { Protein }\end{array}$ & $\begin{array}{l}\text { Extrato etéreo } \\
\text { Ether extract }\end{array}$ \\
\hline Dissecação (dissection) & $85,2^{\mathrm{A}}$ & $14,8^{\mathrm{A}}$ & $60,5^{\mathrm{A}}$ & $18,7^{\mathrm{A}}$ & $14,8^{\mathrm{B}}$ \\
\hline Seção HH (HH section) & $86,8^{\mathrm{A}}$ & $14,6^{\mathrm{A}}$ & $55,1^{\mathrm{B}}$ & $19,3^{\mathrm{A}}$ & $19,5^{\mathrm{A}}$ \\
\hline $\mathrm{CV}, \%$ & 3,4 & 16,8 & 6,4 & 10,0 & 25,2 \\
\hline
\end{tabular}

Médias seguidas de pelo menos uma mesma letra na coluna não diferem a $1 \%$ de probabilidade pelo teste $\mathrm{F}$.

Means followed by the same letter, within a column, do not differ at $1 \%$ of probability by $F$ test.

Tabela 8 - Médias e coeficientes de variação (CV, \%) para as porcentagens de músculo, gordura e osso, relação músculo:osso (RELMO), relação gordura:músculo (RELGM) e porcentagens de água, proteína e extrato etéreo nas carcaças, em função do nível de concentrado e teor de PB na dieta, nas fases de recria e engorda

Table 8 - Means and coefficients of variation (CV, \%) for the percentages of muscle, fat and bone, muscle:bone relation (RELMO), fat:muscle relation (RELGM), and percentages of water, protein and ether extract in the carcass, as a function of the concentrate level and $\mathrm{CP}$ content in the diet, in the growing and fattening phases

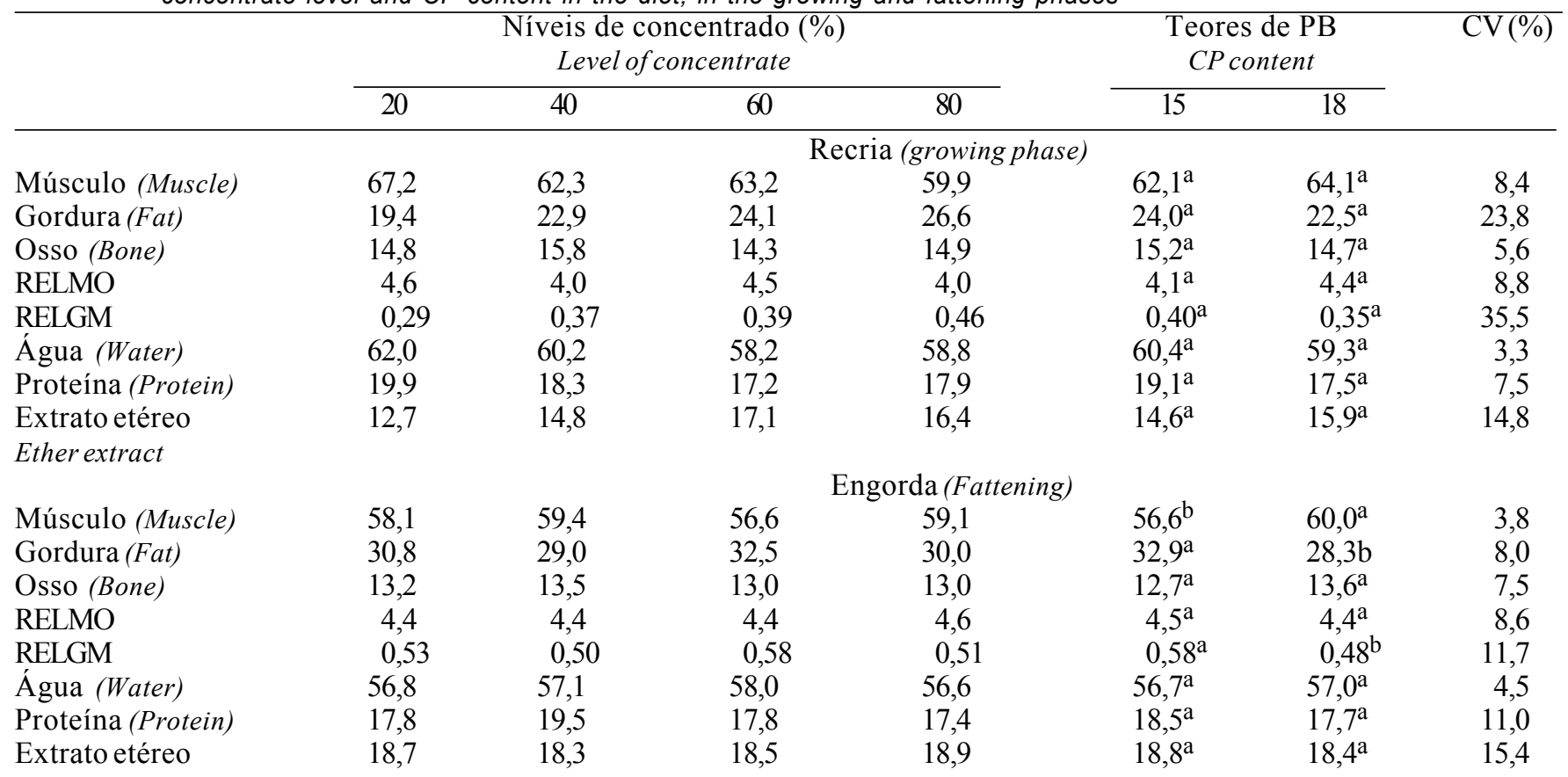

Ether extract

Médias seguidas de pelo menos uma mesma letra na linha, para os teores de PB, não diferem a $1 \%$ de probabilidade pelo teste $\mathrm{F}$ (Means followed by the same letter, within a row, for the CP contents, do not differ at $1 \%$ of probability by $F$ test). 
composição química da seção HH, mas o mesmo não ocorreu para os teores de proteína.

Poucos são os trabalhos, no Brasil, que tentaram validar a utilização das equações de predição de Hankins e Howe para a composição da carcaça. Pelos trabalhos existentes, pode-se observar que a seção HH é um bom indicativo da composição física da carcaça, mas que precisa ser objeto de maior número de investigações, comparando vários grupos genéticos, em diferentes graus de acabamento ou idade, e sobre diferentes manejos alimentares, para que se possa validar a sua utilização, principalmente para estimar a composição química da carcaça.

As composições física e química da carcaça são apresentadas na Tabela 8 . Na fase de recria, existiu tendência de aumento da porcentagem de gordura e de extrato etéreo e de diminuição da porcentagem de músculo e de proteína na carcaça com o aumento dos níveis de concentrado na dieta, fato esperado em função do aumento do consumo de energia com o aumento dos níveis de concentrado na dieta. Entretanto, este maior consumo de concentrado, na fase de engorda, não foi suficiente par alterar a composição física e química da carcaça. Oliveira (1998), Ferreira et al. (2000) e Gesualdi Jr. et al. (2000) também não observaram efeito dos níveis de concentrado sobre a porcentagem de músculo e de gordura da carcaça. Em relação à porcentagem de ossos da carcaça, Ferreira et al. (2000) observaram efeito quadrático e Oliveira (1998) e Gesualdi Jr. et al. (2000), efeito linear decrescente com o aumento dos teores de concentrado da dieta. Trabalhando com Nelore na engorda, Oliveira (1998) encontrou médias de valores de músculo e gordura na carcaça de 54,5 e $29,5 \%$, inferiores aos encontrados neste experimento $(58,3 \mathrm{e}$ $30,6 \%$, respectivamente), em conseqüência da maior porcentagem de ossos na carcaça $(16,0 \times 11,1 \%)$ dos animais do experimento de Oliveira (1998). Ferreira et al. (2000) e Gesualdi Jr. et al. (2000), confinando animais F1 Simental x Nelore e Limousin x Nelore, respectivamente, obtiveram porcentagens de músculo e gordura na carcaça próximas às deste experimento.

$\mathrm{Na}$ fase de recria, os teores de $\mathrm{PB}$ da dieta não influenciaram nenhuma das características físicas e químicas da carcaça, embora tenha sido observada leve tendência das carcaças do tratamento com maior teor de proteína da dieta apresentarem maiores porcentagens de músculo e menores de gordura. Já na engorda, o maior teor de $\mathrm{PB}$ propiciou uma carcaça com maior porcentagem de músculo e menor porcentagem de gordura, levando, conseqüentemente, a apresentar uma carcaça com menor relação gordura:músculo.

$\mathrm{Na}$ Tabela 9 são apresentadas as médias e a equação de regressão ajustada do peso absoluto, em

Tabela 9 - Médias, coeficientes de variação (CV, \%) e equação de regressão ajustada para os pesos absolutos, em kg e em \% do PCVZ, dos rins, baço, coração, pulmões, fígado e gordura interna, em função do nível de concentrado, (NC) e teor de PB na dieta, na fase de recria, e o respectivo coeficiente de determinação $\left(R^{2}\right)$

Table 9 - Means, coefficients of variation (CV, \%) and fitted regression equation for the absolute weights, in $\mathrm{kg}$ and \% EBW, of kidney, spleen, heart, lungs, liver and internal fat, as a function of the concentrate level (NC) and CP content in the diet, in the growing phase, and the respective coefficient of determination $\left(R^{2}\right)$

\begin{tabular}{|c|c|c|c|c|c|c|c|}
\hline & \multicolumn{4}{|c|}{$\begin{array}{c}\text { Níveis de concentrado }(\%) \\
\text { Level of concentrate }\end{array}$} & \multicolumn{2}{|c|}{$\begin{array}{l}\text { Teores de } \mathrm{PB} \\
C P \text { content }\end{array}$} & \multirow[t]{2}{*}{$\mathrm{CV}(\%)$} \\
\hline & 20 & 40 & 60 & 80 & 15 & 18 & \\
\hline & \multicolumn{7}{|c|}{$\mathrm{kg}$} \\
\hline Rins (Kidney) & 0,66 & 0,64 & 0,71 & 0,74 & 0,69 & 0,69 & 9,8 \\
\hline Baço (Spleen) & 1,1 & 1,0 & 1,1 & 1,1 & 1,1 & 1,0 & 14,5 \\
\hline Pulmões (Lungs) & 2,1 & 2,2 & 2,6 & 2,7 & 2,5 & 2,3 & 27,8 \\
\hline Fígado (Liver) & 4,1 & 4,7 & 4,7 & 4,5 & 4,2 & 4,8 & 17,6 \\
\hline \multirow{2}{*}{$\begin{array}{l}\text { Gordura interna } 1 \\
\text { Internal fat }\end{array}$} & 10,7 & 14,0 & 14,7 & 12,5 & 12,5 & 13,5 & 12,2 \\
\hline & \multicolumn{7}{|c|}{$\% \operatorname{PCVZ}(\% \mathrm{EBW})$} \\
\hline Rins (Kidney) & 0,22 & 0,20 & 0,23 & 0,23 & 0,23 & 0,21 & 12,3 \\
\hline Baço (Spleen) & 0,36 & 0,31 & 0,35 & 0,35 & 0,36 & 0,32 & 17,9 \\
\hline Coração (Heart) & 0,39 & 0,37 & 0,44 & 0,39 & 0,41 & 0,39 & 9,3 \\
\hline Pulmões (Lungs) & 0,71 & 0,68 & 0,81 & 0,82 & 0,80 & 0,72 & 24,1 \\
\hline Fígado (Liver) & 1,4 & 1,5 & 1,5 & 1,4 & 1,4 & 1,5 & 14,2 \\
\hline $\begin{array}{l}\text { Gordura interna } \\
\text { Internal fat }\end{array}$ & 3,6 & 4,4 & 4,7 & 3,9 & 4,1 & 4,2 & 14,4 \\
\hline
\end{tabular}

${ }^{1} \hat{Y}=4,61988+0,372351^{* *} n c-0,003421^{* *} n c^{2} \mathrm{R}^{2}=0,99$

** Significativo a $1 \%$ de probabilidade, pelo teste $t$ (significant at $1 \%$ of probability by $t$ test).

R. Bras. Zootec., v.31, n.4, p.******, 2002 
$\mathrm{kg}$, e relativo, em \% do peso de corpo vazio (PCVZ), dos órgãos e da gordura interna, em função dos níveis de concentrado e do teor de PB da dieta, na fase de recria.

$\mathrm{Na}$ fase de recria, os pesos dos rins, baço, pulmões e fígado não foram influenciados $(\mathrm{P}>0,05)$ pelos níveis de concentrado e pelos teores de $\mathrm{PB}$ da dieta, independentemente da forma expressa. O peso absoluto da gordura interna apresentou resposta quadrática, estimando-se valor máximo de $14,75 \mathrm{~kg}$ com uma dieta com $54,42 \%$ de concentrado. A gordura interna, quando foi expressa em relação ao PCVZ, não foi influenciada pelos níveis de concentrado. A explicação para esta ausência de resposta, com o aumento dos níveis de concentrado nas dietas, pode estar no bom valor nutritivo do volumoso utilizado (Tabela 2), pois, mesmo a dieta com maior participação de volumoso supriu nutrientes (energia) suficientes para o máximo desenvolvimento dos órgãos. O menor teor de proteína $(15 \%)$ das dietas estudadas poderia ser suficiente para o bom desenvolvimento dos órgãos, justificando a ausência de resposta do aumento dos níveis de proteína da dieta sobre o peso dos órgãos.

$\mathrm{Na}$ Tabela 10 são apresentados os pesos absolutos e relativos do rúmen-retículo (RURE), omaso (OMA), abomaso (ABO), conjunto de estômagos,
(ESTO), intestino delgado (ID), intestino grosso (IG), conjunto de intestinos (INTES) e o conjunto do trato gastrointestinal (TGI), na fase de recria.

Houve interação $(\mathrm{P}<0,05)$ dos níveis de concentrado com o teor de $\mathrm{PB}$ da dieta para os pesos absolutos, em $\mathrm{kg}$, do intestino delgado e do conjunto de intestinos (Tabela 11). Nesta fase, os constituintes do trato gastrintestinal não foram influenciados pelos níveis de concentrado da dieta. A explicação pode ser a mesma da ausência de resposta em relação aos órgãos.

Os pesos absolutos do coração, intestino delgado e conjunto dos intestinos são apresentados na Tabela 11, decompostos em níveis de concentrado por teor de PB da dieta, devido à interação existente entre as duas variáveis. Os níveis de concentrado não influenciaram ( $\mathrm{P}>0,05)$ estes constituintes, na dieta com $15 \%$ de PB. $\mathrm{Na}$ dieta com $18 \% \mathrm{~PB}$, o peso do coração apresentou uma resposta cúbica e os do intestino delgado e do conjunto dos intestinos, resposta quadrática. $\mathrm{Na}$ literatura consultada, não foi possível encontrar uma resposta para estes resultados.

Na Tabela 12 são apresentadas as médias do peso absoluto, em $\mathrm{kg}$, e relativo, em \% do peso de corpo vazio (PCVZ), dos órgãos e da gordura interna, em função dos níveis de concentrado e do teor de PB

Tabela 10 - Médias e coeficientes de variação (CV, \%) para os pesos absolutos, em kg e em porcentagem do peso de corpo vazio (\% PCVZ) do rúmen-retículo (RURE), omaso (OMS), abomaso (ABO), estômagos (ESTO), intestino delgado (ID), intestino grosso (IG), intestinos (INTES) e trato gastrintestinal (TGI) em função do nível de concentrado (NC) e teor de PB na dieta, na fase de recria

Table 10 - Means and coefficients of variation (CV, \%) for the absolute weights, in $\mathrm{kg}$ and \% empty body weight (\%EBW), of rumenreticulum (RURE), omasum (OMS), abomasum (ABO), stomachs (ESTO), thin intestine (TI) large intestine (as a function of the concentrate level (NC) and CP content in the diet, in the growing phase, and the respective coefficient of determination $\left(R^{2}\right)$

\begin{tabular}{|c|c|c|c|c|c|c|c|}
\hline & \multicolumn{4}{|c|}{$\begin{array}{l}\text { Níveis de concentrado (\%) } \\
\text { Level of concentrate }\end{array}$} & \multicolumn{2}{|c|}{$\begin{array}{l}\text { Teores de PB } \\
C P \text { content }\end{array}$} & \multirow[t]{2}{*}{$\mathrm{CV}(\%)$} \\
\hline & 20 & 40 & 60 & 80 & 15 & 18 & \\
\hline RURE & 5,5 & 5,4 & 5,2 & 5,4 & 5,3 & 5,5 & 17,1 \\
\hline OMA & 2,1 & 2,0 & 1,6 & 1,6 & 1,7 & 1,9 & 28,3 \\
\hline $\mathrm{ABO}$ & 0,81 & 0,84 & 0,80 & 0,83 & 0,77 & 0,87 & 33,5 \\
\hline ESTO & 8,5 & 8,3 & 7,7 & 7,8 & 7,8 & 8,3 & 20,7 \\
\hline $\mathrm{IG}$ & 2,3 & 2,2 & 2,5 & 2,5 & 2,4 & 2,4 & 8,3 \\
\hline \multirow[t]{2}{*}{ TGI } & 14,3 & 14,5 & 14,9 & 14,2 & 14,2 & 14,8 & 12,4 \\
\hline & \multicolumn{7}{|c|}{$\% \operatorname{PCVZ}(\% E B W)$} \\
\hline RURE & 1,9 & 1,7 & 1,6 & 1,7 & 1,7 & 1,7 & 14,6 \\
\hline OMA & 0,71 & 0,63 & 0,51 & 0,49 & 0,56 & 0,61 & 25,2 \\
\hline $\mathrm{ABO}$ & 0,27 & 0,26 & 0,25 & 0,25 & 0,25 & 0,27 & 30,9 \\
\hline ESTO & 2,8 & 2,6 & 2,4 & 2,4 & 2,5 & 2,6 & 17,9 \\
\hline ID & 1,2 & 1,3 & 1,5 & 1,2 & 1,3 & 1,3 & 14,3 \\
\hline IG & 0,76 & 0,70 & 0,80 & 0,78 & 0,79 & 0,73 & 7,7 \\
\hline INTES & 2,0 & 2,0 & 2,3 & 2,0 & 2,1 & 2,0 & 10,1 \\
\hline TGI & 4,8 & 4,5 & 4,7 & 4,4 & 4,6 & 4,6 & 10,7 \\
\hline
\end{tabular}

R. Bras. Zootec., v.31, n.4, p..**_***, 2002 
da dieta, na fase de engorda. Os níveis de concentrado não influenciaram $(\mathrm{P}>0,05)$ o peso dos órgãos e da gordura interna, contrariando os resultados da literatura, que relata aumento linear do peso dos rins, baço, fígado e gordura interna, com o aumento do nível energético da dieta (Jones et al. 1985; Ferreira et al.,
2000; Véras et al. (2001). Possivelmente, o que realmente ocorre é uma diminuição do tamanho destes órgãos, quando a concentração energética da dieta está abaixo do potencial genético dos animais (Peron et al., 1993; Jorge et al., 1999), numa tentativa de priorizar nutrientes para outros órgãos vitais,

Tabela 11 - Médias e equações de regressão ajustadas para os pesos absolutos, em kg, do coração, intestino delgado (ID) e intestinos (INTES), em função do nível de concentrado e teor de PB na fase de recria

Table 11 - Means and fitted regression equations for absolute weights, in $\mathrm{kg}$, of heart, thin intestine (TI), and intestines (INTES), as a function of the concentrate level and CP content, in the growing phase

\begin{tabular}{|c|c|c|c|c|c|}
\hline \multirow[b]{2}{*}{$\begin{array}{l}\text { Teor de PB } \\
C P \text { content }\end{array}$} & \multicolumn{4}{|c|}{$\begin{array}{l}\text { Nível de concentrado (\%) } \\
\text { Concentrate level }\end{array}$} & \multirow[b]{2}{*}{$\begin{array}{l}\text { Equação } \\
\text { Equation }\end{array}$} \\
\hline & 20 & 40 & 60 & 80 & \\
\hline \multicolumn{6}{|l|}{$\begin{array}{l}\text { Coração } \\
\text { Heart }\end{array}$} \\
\hline 15 & 1,2 & 1,3 & 1,2 & 1,4 & $\hat{Y}=1,26$ \\
\hline $\begin{array}{l}18 \\
\text { ID } \\
T I\end{array}$ & 1,2 & 1,1 & 1,6 & 1,2 & $\hat{Y}=3,3209-0,1852 * * n c+0,00446 * * n c^{2}-0,00003 * * n c^{3} r^{2}=0,99$ \\
\hline 15 & 4,1 & 4.3 & 4,0 & 3,6 & $\hat{Y}=4,00$ \\
\hline $\begin{array}{l}18 \\
\text { INTES }\end{array}$ & 3,1 & 3,7 & 5,5 & 4,2 & $\hat{Y}=0,4682+0,1448 * * \mathrm{nc}-0,0012 * \mathrm{nc}^{2} \mathrm{r}^{2}=0,69$ \\
\hline 15 & 6,4 & 6,6 & 6,3 & 6,4 & $\hat{Y}=6,43$ \\
\hline 18 & 5,4 & 5,9 & 8,2 & 6,4 & $\hat{Y}=2,1535+0,1749 * * \mathrm{nc}-0,00148 * * \mathrm{nc}^{2} \mathrm{r}^{2}=0,63$ \\
\hline
\end{tabular}

Tabela 12 - Médias e coeficientes de variação (CV, \%) para os pesos absolutos, em kg e em \% do PCVZ, dos rins, baço, coração, pulmões, fígado e gordura interna em função do nível de concentrado (nc) e teor de PB na dieta, na fase de engorda

Table 12 - Means and coefficients of variation (CV, \%) for absolute weights, in $\mathrm{kg}$ and \% EBW, of kidney, spleen, lungs, liver and internal fat, as a function of the concentrate levels and CP content in the diet, in the fattening phase

\begin{tabular}{|c|c|c|c|c|c|c|c|}
\hline & \multicolumn{4}{|c|}{$\begin{array}{c}\text { Níveis de concentrado (\%) } \\
\text { Level of concentrate }\end{array}$} & \multicolumn{2}{|c|}{$\begin{array}{c}\text { Teores de } \mathrm{PB} \\
\text { CP content }\end{array}$} & \multirow[t]{2}{*}{$\mathrm{CV}(\%)$} \\
\hline & 20 & 40 & 60 & 80 & 15 & 18 & \\
\hline & \multicolumn{7}{|c|}{$\mathrm{kg}$} \\
\hline Rins (Kidney) & 0,81 & 0,76 & 0,79 & 0,71 & $0,72 b$ & $0,82 \mathrm{a}$ & 6,8 \\
\hline Baço (Spleen) & 1,1 & 1,1 & 1,0 & 1,2 & $1,1 \mathrm{a}$ & $1,1 \mathrm{a}$ & 9,2 \\
\hline Coração (Heart) & 1,4 & 1,4 & 1,4 & 1,4 & $1,4 \mathrm{a}$ & $1,4 \mathrm{a}$ & 4,0 \\
\hline Pulmões (Lungs) & 2,3 & 2,3 & 2,2 & 2,2 & $2,1 \mathrm{~b}$ & $2,4 \mathrm{a}$ & 11,6 \\
\hline Fígado (Liver) & 4,8 & 4,7 & 5,0 & 4,7 & $4,5 \mathrm{~b}$ & $5,2 \mathrm{a}$ & 6,9 \\
\hline \multirow[t]{2}{*}{$\begin{array}{l}\text { Gordura interna } \\
\text { Internal fat }\end{array}$} & 17,9 & 25,6 & 25,6 & 22,2 & $22,6 a$ & $23,1 \mathrm{a}$ & 30,7 \\
\hline & \multicolumn{7}{|c|}{$\% \operatorname{PCVZ}(\% E B W)$} \\
\hline Rins (Kidney) & 0,21 & 0,19 & 0,20 & 0,18 & $0,18 b$ & $0,21 \mathrm{a}$ & 6,9 \\
\hline Baço (Spleen) & 0,28 & 0,28 & 0,25 & 0,31 & $0,28 \mathrm{a}$ & $0,28 \mathrm{a}$ & 12,3 \\
\hline Coração (Heart) & 0,36 & 0,35 & 0,35 & 0,34 & $0,35 \mathrm{a}$ & $0,35 \mathrm{a}$ & 5,9 \\
\hline Pulmões (Lungs) & 0,60 & 0,58 & 0,54 & 0,55 & $0,53 b$ & $0,61 \mathrm{a}$ & 8,9 \\
\hline Fígado (Liver) & 1,3 & 1,2 & 1,3 & 1,2 & $1,1 \mathrm{~b}$ & $1,3 \mathrm{a}$ & 4,4 \\
\hline Gordura interna & 4,7 & 6,6 & 6,4 & 5,5 & $5,8 \mathrm{a}$ & $5,9 \mathrm{a}$ & 30,1 \\
\hline
\end{tabular}

Médias seguidas de pelo menos uma mesma letra na linha, para os teores de PB, não diferem a $1 \%$ de probabilidade pelo teste F. Means followed by the same letter in a row, for the CP contents, do not differ at $1 \%$ of probability by $F$ test.

R. Bras. Zootec., v.31, n.4, p.***_** 2002 
como coração, pulmões e cérebro. Como neste experimento as dietas com menores níveis de concentrado já apresentaram bom valor energético, como pode ser observado pelo valor de NDT na Tabela 2, elas não permitiram que o tamanho dos órgãos diminuísse. Já os teores de $\mathrm{PB}$ influenciaram positivamente $(\mathrm{P}<0,05)$ os pesos absolutos e relativos dos rins, pulmões e fígado.

$\mathrm{Na}$ Tabela 13 são apresentados as médias e as equações de regressão ajustadas para os pesos absolutos e relativos do rúmen-retículo (RURE), omaso (OMA), abomaso (ABO), conjunto de estômagos, (ESTO), intestino delgado (ID), intestino grosso (IG), conjunto de intestinos (INTES) e o conjunto do trato gastrointestinal (TGI), na fase de engorda.

Os pesos do ABO, ID, IG e INTES não foram influenciados pelos níveis de concentrado da dieta. Os pesos relativos do RURE, OMA, ESTO e TGI apresentaram comportamento linear decrescente com o aumento dos níveis de concentrado. Possivelmente, esta diminuição do peso do TGI, na fase de engorda, tenha sido causada pela menor quantidade do conteúdo do trato gastrintestinal das dietas com maiores teores de concentrado (Tabela 3). Já Ferreira et al. (2000) observaram respostas lineares crescentes para a maioria dos pesos dos constituintes do trato gastrintestinal e quadrática para o peso do rúmenretículo. Véras et al. (2001) também observou resposta quadrática para o peso do rúmen-retículo, mas demonstrou ausência de resposta para a maioria dos pesos dos outros constituintes do TGI.

Os teores de $\mathrm{PB}$ não influenciaram $(\mathrm{P}>0,05)$ os pesos dos constituintes do TGI em nenhuma das

Tabela 13 - Médias, coeficientes de variação (CV, \%) e equações de regressão ajustadas para os pesos absolutos, em $\mathrm{kg}$ e em porcentagem do peso de corpo vazio (\% PCVZ) do rúmen-retículo (RURE), omaso (OMS), abomaso (ABO), estômagos (ESTO), intestino delgado (ID), intestino grosso (IG), intestinos (INTES) e trato gastrintestinal (TGI), em função do nível de concentrado (NC) e teor de PB na dieta, na fase de engorda, e os respectivos coeficientes de determinação $\left(r^{2}\right)$

Table 13 - Means, coefficients of variation (CV, \%) and fitted regression equations for the absolute weights, in $\mathrm{kg}$ and \% empty body weight (\%EBW) of rumen-reticulum (RURE), omasum (OMS), abomasums (ABO), stomachs (ESTO), small intestine (TI), large intestine (LI), intestines (INTEST) and gastrointestinal tract (TGI), as a function of the concentrate levels (CL) and CP content in the diet, in the fattening phase, and the respective coefficients of determination $\left(r^{2}\right)$

\begin{tabular}{|c|c|c|c|c|c|c|c|}
\hline & \multicolumn{4}{|c|}{$\begin{array}{l}\text { Níveis de concentrado }(\%) \\
\text { Level of concentrate }\end{array}$} & \multicolumn{2}{|c|}{$\begin{array}{l}\text { Teores de PB } \\
C P \text { content }\end{array}$} & \multirow[t]{2}{*}{$\mathrm{CV}(\%)$} \\
\hline & 20 & 40 & 60 & 80 & 15 & 18 & \\
\hline & \multicolumn{7}{|c|}{$\mathrm{kg}$} \\
\hline Rins (Kidney) & 0,81 & 0,76 & 0,79 & 0,71 & $0,72^{\mathrm{b}}$ & $0,82^{\mathrm{a}}$ & 6,8 \\
\hline RURE1 & 6,6 & 5,6 & 4,9 & 4,8 & 5,2 & 5,8 & 12,5 \\
\hline OMA & 2,4 & 1,9 & 2,1 & 1,7 & 1,9 & 2,1 & 14,8 \\
\hline $\mathrm{ABO}$ & 0,9 & 0,9 & 0,9 & 1,0 & 0,9 & 1,0 & 10,13 \\
\hline ESTO2 & 9,9 & 8,4 & 7,9 & 7,5 & 8,0 & 8,8 & 11,23 \\
\hline ID & 3,8 & 4,6 & 4,3 & 4,6 & 4,2 & 4,5 & 11,8 \\
\hline IG & 2,8 & 3,0 & 2,9 & 2,8 & 2,8 & 2,9 & 8,6 \\
\hline INTES & 6,6 & 7,6 & 7,2 & 7,4 & 7,0 & 7,4 & 7,5 \\
\hline \multirow[t]{2}{*}{ TGI } & 16,5 & 16,0 & 15,0 & 14,8 & 15,0 & 16,2 & 6,9 \\
\hline & \multicolumn{7}{|c|}{$\% \operatorname{PCVZ}(\% E B W)$} \\
\hline RURE3 & 1,7 & 1,4 & 1,2 & 1,2 & 1,3 & 1,5 & 9,9 \\
\hline OMA4 & 0,62 & 0,48 & 0,52 & 0,51 & 0,49 & 0,53 & 13,0 \\
\hline $\mathrm{ABO}$ & 0,24 & 0,24 & 0,22 & 0,26 & 0,23 & 0,25 & 9,6 \\
\hline ESTO5 & 2,6 & 2,2 & 2,0 & 1,9 & 2,0 & 2,2 & 8,5 \\
\hline ID & 1,0 & 1,2 & 1,1 & 1,2 & 1,1 & 1,1 & 13,3 \\
\hline $\mathrm{IG}$ & 0,72 & 0,77 & 0,71 & 0,70 & 0,70 & 0,75 & 7,75 \\
\hline INTES & 1,7 & 1,9 & 1,8 & 1,9 & 1,8 & 1,9 & 8,6 \\
\hline TGI6 & 4,3 & 4,1 & 3,8 & 3,7 & 3,8 & 4,1 & 4,9 \\
\hline
\end{tabular}

\footnotetext{
${ }^{1} \hat{Y}=6,98825-0,02944^{* *} \mathrm{NC} \mathrm{r}^{2}=0,91$

$2 \hat{Y}=10,3260-0,03803^{* *} \mathrm{NC} \mathrm{r}^{2}=0,90$

${ }^{3} \hat{Y}=1,82965-0,00846^{* *} \mathrm{NC} r^{2}=0,90$

${ }^{4} \hat{Y}=0,65094-0,00294^{\star *} N C r^{2}=0,80$;

$5 \hat{Y}=2,70771-0,01120^{* *} \mathrm{NC} \mathrm{r}^{2}=0,90$

${ }^{6} \hat{Y}=4,47200-0,00995^{\star *} \mathrm{NC} \mathrm{r}^{2}=0,94$;

** Significativo a $1 \%$ de probabilidade, pelo teste $t$ (significant at $1 \%$ of probability by $t$ test).
} 
formas expressas nas duas fases estudadas. $\mathrm{O}$ menor teor de proteína $(15 \%)$ das dietas estudadas poderia ser suficiente para o bom desenvolvimento constituintes do TGI, justificando os resultados.

\section{Conclusões}

Animais na engorda suportam maiores níveis de concentrado na dieta, sem apresentar redução no consumo de MS em relação a animais mais leves (recria).

Os teores de PB das dietas de animais zebu em recria foram maiores que os recomendados pelo NRC (1996), pois houve resposta no ganho de peso com aumento do teor de PB na dieta.

O aumento dos níveis de concentrado na dieta pode aumentar o rendimento de carcaça, pois o peso do conteúdo do trato gastrintestinal é reduzido com o aumento dos níveis de concentrado na dieta.

A seção HH pode ser utilizada para estimar a composição física e o teor de proteína da carcaça, não sendo recomendada para estimar os teores de água e extrato etéreo, confirmando a necessidade do desenvolvimento de equações específicas para diferentes grupos genéticos.

Maiores teores de PB da dieta podem aumentar a porcentagem de músculo e diminuir a de gordura na carcaça.

Maiores teores de PB na dieta podem elevar o peso dos rins, pulmões e fígado.

Os pesos do rúmen-retículo e do omaso são menores em dietas com maiores níveis de concentrado, devido aos menores pesos do conteúdo do trato gastrintestinal em dietas com maiores níveis de concentrado.

\section{Literatura Citada}

AINSLIE, S.J.; FOX, D.G.; PERRY, T.C. et al. Predicting amino acid adequacy of diets fed to Holstein steers. Journal of Animal Science, v.71, p.1312-1319, 1993.

ALLEONI, G.F.; BOIN, C.; LEME, P.R. et al. Avaliação da composição química e física dos cortes da costela para estimar a composição química corporal de novilhos Nelore. Revista Brasileira de Zootecnia, v.26, n.2, p.382-390, 1997.

ARAÚJO, G.G.L.; SILVA., J.F.C.; VALADARES FILHO, S.C. et al. Ganho de peso, conversão alimentar e características da carcaça de bezerros alimentados com dietas contendo diferentes níveis de volumoso. Revista Brasileira de Zootecnia, v.27, n.5, p.1006-1012, 1998.

BERG, R.T.; BUTTERFIELD, R.M. Nuevos conceptos sobre desarrollo de ganado vacuno. In: EI crecimiento del ganado vacuno y la producción de carne de vacuno. Zaragoza: Acribia, 1979. p.16-29.

CONRAD, H.R.; PRATT, A.D.; HIBBS, J.W. Regulation of feed intake in dairy cows. 1. Change in importance of physical and physiological factors with increasing digestibility. Journal of Dairy Science, v.47, p.54-60, 1964.

FERREIRA, M.A., VALADARES FILHO, S.C., MUNIZ, E.B. et al. Características das carcaças, biometria do trato gastrointestinal, tamanho dos órgãos internos e conteúdo gastrointestinal de bovinos F1 Simental x Nelore alimentados com dietas contendo vários níveis de concentrado. Revista Brasileira de Zootecnia, v. 29, n.4, p.1174-1182, 2000.

FERREIRA, M.A.; VALADARES FILHO, S.C.; SILVA, J.F.C. et al. Consumo, conversão alimentar, ganho de peso e características da carcaça de bovinos F1 Simental x Nelore. Revista Brasileira de Zootecnia, v.28, n.2, p.343-351, 1999.

GALVÃO, J.G.; FONTES, C.A.A.; PIRES, C.C. et al. Características e composição física da carcaça de bovinos nãocastrados, abatidos em três estágios de maturidade (estudo II) de três grupos raciais. Revista da Sociedade Brasileira de Zootecnia, v.20, n.5, p.502-512, 1991.

GESUALDI Jr., A.; PAULINO, M.F.; VALADARES FILHO, S.C. et al. Níveis de concentrado na dieta de novilhos F1 Limousin x Nelore: características de carcaça. Revista Brasileira de Zootecnia, v.29, n.5, p.1467-1473, 2000.

HANKINS, O.G.; HOWE, P.E. Estimation of the composition of beef carcasses and cuts. Washington, D.C., 1946. (Technical Bulletin - USDA, 926).

ÍTAVO, L.C.V. Níveis de concentrado e proteína bruta na dieta de bovinos Nelore nas fases de recria e terminação: consumo e digestibilidade. Revista Brasileira de Zootecnia, v.31, n.2(S), p.1033-1041, 2002.

JOHNSON, D.E.; JOHNSON, K.A.; BALDWIN, R.L. Changes in liver and gastrointestinal tract energy demands in response to physiological workload in ruminants. Journal of Nutrition, v.120, n.2, p.649-655, 1990.

JONES, S.D.M.; ROMPALA, R.E.; JEREMIAH, L.E. Growth and composition of the empty body in steers of different maturity types fed concentrate or forage diets. Journal of Animal Science, v.60, n.2, p.427-433, 1985.

JORGE, A.M. Ganho de peso, conversão alimentar e características da carcaça de bovinos e bubalinos. Viçosa, MG: Universidade Federal de Viçosa, 1993. 97p. Dissertação (Mestrado em Zootecnia) - Universidade Federal de Viçosa, 1993.

JORGE, A.M.; FONTES, C.A.; PAULINO, M.F. et al. Tamanho relativo dos órgãos internos de zebuínos sob alimentação restrita e ad libitum. Revista Brasileira de Zootecnia, v.29, n.4, p.1174-1182, 1999.

JORGE, A.M.; FONTES, C.A.; SOARES, J.E. et al. Características quantitativas da carcaça de bovinos e bubalinos, abatidos em diferentes estádios de maturidade. Revista Brasileira de Zootecnia, v.26, n.5, p.1039-1047, 1997.

LUCHIARI FILHO, A. Pecuária da carne bovina. 1.ed. São Paulo: editora??, 2000. 134p.

MEISSNER, H.H.; SMUTS, M.; COERTZE, R.J. Caracteristics and efficiency of fast growing feedlot steers fed different dietary energy concentration. Journal of Animal Science, v.73, n.4, p.931-936, 1995.

MOLETTA, J.L.; RESTLE, J. Características de carcaças de novilhos de diferentes grupos genéticos terminados em confinamento. Revista da Sociedade Brasileira de Zootecnia, v.25, n.5, p.876-888, 1996.

MOURA, A.C.; LUCHIARI FILHO, A.; JUNQUEIRA, F.J. Avaliação de carcaças de bovinos jovens $1 / 2$ Beefalo $+1 / 2$ Nelore, $1 / 2$ Canchim $+1 / 2$ Nelore e Nelore tipo comercial. Revista Brasileira de Zootecnia, v.27, n.4, p.797-800, 1998.

MÜLLER, L. Normas para avaliação de carcaças e concurso

R. Bras. Zootec., v.31, n.4, p. ${ }^{\star \star *}{ }^{\star * *}, 2002$ 
de carcaças de novilhos. Santa Maria: Universidade Federal de Santa Maria, 1987. 31p.

MUNIZ, E.B.; VALADARES FILHO, S.C.; SILVA, J.F.C. et al. Características das carcaças de novilhos $\mathrm{F}_{1}$ simental $\mathrm{x}$ nelore alimentados com vários níveis de concentrado. In: REUNIÃO ANUAL DA SOCIEDADE BRASILEIRA DE ZOOTECNIA, 34., 1997, Juiz de Fora. Anais... Juiz de Fora: Sociedade Brasileira de Zootecnia, 1997. p.328.

NATIONAL RESEARCH COUNCIL - NRC. Nutrients requirements of beef cattle. 7.ed. Washington, D.C.: 1996. $242 p$.

NOUR, A.Y.M.; THONNEY, M.L. Chemical composition of angus and Holstein carcasses predicted from rib section composition. Journal of Animal Science, v.72, p.12391241, 1994.

OLIVEIRA. S.R. Desempenho e características da carcaça de novilhos Nelores não-castrados. Viçosa, MG: Universidade Federal de Viçosa, 1998. 58p. Dissertação (Mestrado em Zootecnia) - Universidade Federal de Viçosa, 1998.

OWENS, F.N.; DUBESKI, P.; HANSON, C.F. Factors that alter the growth and development of ruminants. Journal of Animal Science, v.71, p.3138-3150, 1993.

OWENS, F.N.; GILL, D.R.; SECRIST, D.S. et al. Review of some aspects of growth and development of feedlot cattle. Journal of Animal Science, v.73, p.3152-3172, 1995.

PATTERSON, D.C.; STEEN, R.W.; KILPATRICK, D.J. Growth and development in beef cattle. 1. Direct and residual effect of plane of nutrition during early life on components of gain and food efficiency. Journal of Agriculture Science, v.124, n.1, p.91-100, 1995.
PERON, A.J.; FONTES, C.A.A.; LANA, R.P. et al. Tamanho dos órgãos internos e distribuição da gordura corporal em novilhos de cinco grupos genéticos, submetidos à alimentação restrita e "ad libitum". Revista da Sociedade Brasileira de Zootecnia, v.22, n.5, p.813-819, 1993.

PRESTON, T.R.; WILLIS, M.B. Intensive beef production. 2.ed. Oxford: Pergamon Press, 1974. 546p.

SILVA, D.J. Análise de alimentos (métodos químicos e biológicos). Viçosa: Universidade Federal de Viçosa, 1990. 165p.

UNIVERSIDADE FEDERAL DE VIÇOSA - UFV. SAEG Sistema de análises estatísticas e genética. Viçosa, MG: Universidade Federal de Viçosa, 1995. (Apostila).

VÉRAS, A.S.C.; VALADARES FILHO, S.C.; SILVA, J.F.C. et al. Consumo e digestibilidade aparente em bovinos Nelore, não - castrados, alimentados com rações contendo diferentes níveis de concentrado. Revista Brasileira de Zootecnia, v.29, n.6, p.2367-2378, 2000.

VÉRAS, A.S.C.; VALADARES FILHO, S.C.; SILVA, J.F.C. et al. Efeito do nível de concentrado sobre o peso dos órgãos internos e do conteúdo gastrintestinal de bovinos Nelore nãocastrados. Revista Brasileira de Zootecnia, v.30, n.3(S), p.1120-1126, 2001. 